\title{
Is COVID-19 forcing ESL instructors to return to more traditional teaching in the second language acquisition methodology?
}

ISSN 2657-9774; https://doi.org/10.36534/erlj.2021.01.02

\author{
Emina Lagumdžija*, Anisa Eminović-Ljevo** \\ *International University of Sarajevo, Bosnia and Herzegovina; elagumdzija@ius.edu.ba \\ **International University of Sarajevo, Bosnia and Herzegovina; aeminovic@ius.edu.ba
}

\begin{abstract}
This paper is part of PhD research conducted by two experienced ESL instructors from the International University of Sarajevo. The aim was to see whether the instructors at the English Language School (ELS) at the International University of Sarajevo (IUS) were turning to some more traditional teaching methods and techniques due to the COVID-19 pandemic and emergency online instruction. Four experienced English Language School instructors were interviewed and special attention was paid to the following aspects of teaching: class activities, feedback, teacher talking time and student-instructor rapport. The results showed that despite being fully experienced with and knowledgeable about modern teaching methods and techniques, more traditional methods seemed to be preferred to modern teaching methods when it came to online instruction. However, to prove this even further, some large-scale and more empirical studies would have to be conducted in the future.
\end{abstract}

Keywords: in-person instruction, online instructions, modern methodology, traditional methodology, class activities, feedback, teacher talking time, student-instructor rapport

\section{Introduction}

The world was put to a stop in the spring of 2020 due to the COVID-19 pandemic and it affected almost all aspects of our lives - work, education, shopping, travelling, to name just a few. Thanks to modern technology, education was able to resume its function online, which was crucially important to many students and teachers all around the world who would have lost their opportunity to study or do their jobs. However, the situation has generated a very important question whether all of us who have gotten used to modern teaching methodology and have been applying it in our classrooms for many years will have to go back and start applying some more traditional methods due to the fact that instruction has been moved online. Online and in-person instruction share many similarities in terms of applying both modern as well as traditional methods in our teaching. Nevertheless, it needs to be said here that they are not the same and cannot be treated fully equally simply due to the sole fact that the environment in which they are executed is not the same. That is why, it is believed that online instruction might be pushing us, educators, into some more traditional education in which we are starting to re-apply some more traditional techniques in our online classes. The authors of the paper decided to approach the issue from the angle of an English as a second language (ESL) instructor, so we interviewed four experienced ESL instructors in order to get their opinions and views on the issue at hand. This paper will examine whether online instruction makes certain aspects of second language teaching more traditional again including some major factors that might contribute to it.

\section{Literature review \\ COVID 19, online education and traditional education}

Due to COVID-19, defined as "severe acute respiratory syndrome coronavirus 2 (SARS-CoV-2) is a newly identified pathogen and it is assumed there is no pre-existing human immunity to the virus" (CDPC 2020), almost all education has been moved online. It is the type of education in which all 
segments of education such as learning processes, communication between students and academicians, individual and collaborative work are all enabled by the Internet. Furthermore, it means that distance learning can be facilitated thanks to online delivery by making course material available and accessible at any given time and place (Volery and Lord 2000).

On the other hand, in-person learning is defined as:

(...) any form of instructional interaction that occurs "in person" and in real time between teachers and students or among colleagues and peers. Before the advent of audio, video, and internet technologies that allowed people to interact from different locations and at different times, all instructional interactions occurred, by necessity, in the same place and at the same time. (The Glossary of Education Reform for Journalists, Parents, and Community Members)

Although any foreign language teaching methodology focuses mainly on improving the foreign language ability and skills of the student, traditional methodology focuses on skills and abilities in isolation and is generally teacher-centered. As for modern methodology, it is much more studentcentered with the student being the most active element of the teaching/learning process. Students are encouraged to experiment with the language instead of being asked or even forced to memorize grammatical rules and isolated vocabulary. Moreover, modern methodology includes a variety of techniques and activities in which students are exposed to real-life situations and are asked to use the language effectively in those specific simulated situations (Boumová 2008, Richards 1990).

\section{Class activities (pair work, group work, project work)}

We, as educators, are all well aware of the fact that pair work, group and project work are all an integral part of successful learning, especially in terms of acquiring a foreign language. They give our students a fantastic opportunity to practice the target language in a controlled or semi-controlled manner by using it in either pair work or group work or by working together on some projects. In an in-person ESL classroom, they are used to give students more exposure to the target language, but also to reduce the teacher talking time in class. Moreover, this builds the self-confidence of the learner since they know that they are talking to someone whose English is at the same or similar level of proficiency as theirs. It is definitely different from talking to your teacher, who can be both a native or non-native speaker of English (Ballard and Winke 2017), where your confidence is at a much lower level due to the fact that you know they can notice each and every mistake you make both in oral and written communication. It is definitely different from traditional in-person instruction where learners were (and still are) asked to translate from their native into the target language and where all kinds of language practice tasks were (and still are) strictly controlled by the instructor (Palmer 1921).

There are minimum five pedagogical benefits of group work that emphasize its potential "for increasing the quantity of language practice opportunities, for improving the quality of student talk, for individualizing instruction, for creating a positive affective climate in the classroom, and for increasing student motivation." (Long and Porter 1985: 207-208). All of them strongly rely on naturalistic and humanistic approaches that make the learning as well as the teaching process more effective, purposeful and enjoyable (Asher 1977, Krashen 1985, Krashner and Terell 1983, Winitz 1981).

\section{Feedback}

Constructive and timely corrective feedback (CF) is seen as something inevitable in an ESL classroom. It is highly important and necessary and it is an essential part of the teaching/learning process, both in its oral and written form. ESL learners used to believe that only their instructors were supposed to be in charge of giving feedback on their performance. However, due to different classroom management techniques/activities, this view has changed and now peer corrective feedback (PCF) is definitely something that is appreciated by both educators and learners due to its effectiveness. Learners tend to hesitate less to communicate with their peers as well as with their instructors and seem to consider any constructive feedback being given to them as something positive. Needless to say, instructors use many 
different feedback-giving techniques, both online and in-person, depending on the group of learners, their backgrounds and learning objectives.

"Although learner beliefs regarding CF are unanimously positive across contexts, some studies have shown that the extent to which they have a positive view of CF (defined under the framework of grammar instruction) varies depending on learners' cultural backgrounds." (Sato 2013: 612). There are two important factors to be taken into account as far as the effectiveness of the intervention on language development is concerned and they are as follows: a collaborative classroom environment and positive social relationships between learners (Sato 2013). Furthermore, if recasts and translations are used in the classroom by providing students with the correct model, they do not feel the necessity to respond. On the other hand, repetitions, clarification requests, elicitations and metalinguistic feedback generally lead to immediate repair of errors and can result in peer and self-correction (Panova and Lyster 2002). Finally, errors caused by the speaker's L1 are no longer seen as interference, but as developmental. They could be contrastively analyzed and possibly provide evidence of systematic hypothesis (Corder 1967, 1973, Selinker 1972).

\section{Teacher Talking Time (TTT)}

Reducing teacher talking time (TTT) in an ESL classroom has been viewed as one of the most important segments of modern ESL methodology. Obviously, the point of reducing TTT in the classroom stems from the idea that learners should be given as many chances as possible to practice the target language in the classroom (Jarvis and Robinson 1997, McCormick and Donato 2000). This is exactly why all those modern methodological activities, such as pair work, group work, project work, peer corrective feedback and so on, have been introduced and applied in modern ESL classrooms. TTT should be controlled, limited and highly functional. Communicative Language Teaching (CLT) advocates argue that the role of the teacher is to establish different situations in which the learner is the (key) communicator and interaction between learners is encouraged. "Students interact with others, they are actively engaged in negotiation of meaning, they have an opportunity to express themselves by sharing ideas and opinions, and they are responsible for their own learning." (Antón 1999: 303, Brenn 1980 LarsenFreeman 1986, Nunan, 1988, 1989 as cited in Antón 1999).

However, we are facing the situation in our online classes where we are forced to have monologues and talk to "account/profile" pictures of our students/learners. There are always a few students who are constantly active and participate, but most of them are just passive observers and we can only follow their progress through their graded assignments and exams and in individual feedback sessions. Despite the fact that we all try to make our online classes as similar as possible to those in-person ones, we are all aware of the fact that they are simply not the same.

\section{Student-instructor rapport}

Student-instructor rapport is, without a doubt, crucially important to the teaching/learning process, both in-person and online (Bygate, Skehan and Swain 2001, Ellis 2003, Sinclair and Coulthard 1975). It is responsible for creating a positive atmosphere which aids learning and for boosting the motivation of both the instructor and his/her students. Online instruction makes instructors more available for consults and feedback, which additionally makes the learning process easier on students and enables them to acquire the necessary knowledge at a faster pace and more conveniently. However, the question that still needs to be addressed here is whether instructors and learners have the same perception of the class atmosphere online and in-person and whether it is possible to say that the same kind of atmosphere can be created in the two modes of instruction - namely, online and in-person.

Despite their wish to build connection and interpersonal relationships with their students, "instructors realize that they need to establish themselves as an authority figure in the classroom. Finding this balance may be a key to effective rapport building." (Webb and Obrycki Barrett 2014: 20).

Furthermore, Webb and Obrycki Barrett (2014) claim that instructors understood that:

(...) student relationships are quite different depending on the age of the student, and adjusted their behavior to accommodate these changes. This finding illustrates a need to conduct research 
on a various student age levels when examining a rapport-building variable. Findings from a study of rapport in an elementary school classroom likely will not always translate to a college setting.

So, it is obvious that the instructor's skills to find the right balance between establishing himself/herself as authority and building connections and interpersonal relationships with his/her students as well as the student's age are immensely important if we want to build a positive classroom atmosphere.

\section{Student preference between online and in-person education}

In the spring of 2020, both students and educators all around the world found themselves in an unknown and unprecedented situation in modern times due to the outbreak of the COVID-19 pandemic and had to do their best to tackle all sorts of problems that the new situation was presenting them with. All those factors such as their family status, financial situation, health condition and many more had to be taken into consideration and all of them, undoubtedly, impacted the teaching/learning process. Many students mentioned various causes of stress such as: familial, financial, health and other issues that had largely impacted the learning process (Kelly and Columbus 2020).

Overnight, we moved from in person instruction to online instruction, we finished the previous academic year online, tried to start the new one in-person again, but had to move it online due to the rising number of people who tested positive to the virus. However, students were generally not enthusiastic about the emergency online instruction.

An April survey of over 3,000 continuing college students by the education technology firm Top Hat found that most students felt the emergency online instruction was unengaging (78 percent) and inferior to their typical face-to-face experience (68 percent). Yet students were sympathetic to the circumstances their school faced, simultaneously reporting the crisis response of their institution (70 percent) and professors (66 percent) to be good or excellent. (Kelly and Columbus 2020: 3, Top Hat as cited in Kelly and Columbus 2020).

It is clear that the students appreciated the effort and reaction of their professors and institution but still found online instruction not to be engaging or challenging enough as its in-person counterpart. They were obviously aware of the necessity of the undertaken actions and activities but, at the same time, cannot fail to address some obvious drawbacks of the emergency online instruction.

Furthermore, Kelly and Columbus (2020) also make a reference to another survey of over 16,000 incoming and continuing students conducted by the education search platform Niche in which students were offered 10 different scenarios for instruction in the fall. According to the survey,

(...) returning to in-person instruction was by far the most popular choice, appealing to 79 percent of all respondents and a clear majority of continuing undergraduates at two- and four-year colleges. Remaining fully online in the fall was seen as the second-least appealing option (28 percent). Interestingly, 57 percent of continuing undergraduates at two-year colleges responded that remaining online in the fall was appealing, a striking difference from the 24 percent and 36 percent of students at private and public four-year colleges, respectively. ( Niche survey as cited in Kelly and Columbus 2020).

This goes to show that in-person and online instruction are perceived differently by students depending on their year of study. However, in-person instruction still seems to be the most preferred mode of instruction.

Furthermore, there are certain steps that need to be taken before making any final decisions with regard to online vs. in-person instruction. Some of the main issues that have to be taken into account when schools get to resume their in-person instruction and how it affects both students and teachers/instructors. As for the regulatory flexibility, it was noticed that educational institutions were not fully ready for what happened in the spring of 2020 and that most of their rules and regulations were ill-suited for the challenges educational institutions faced back then (Bailey et al. 2020). 


\section{Research questions}

In order to further investigate whether the COVID-19 pandemic has pushed us back into more traditional education, the following questions were designed to guide the data collection and analysis:

1. Do you organize the activities normally conducted in in-person instruction such as pair work, group work and project work in online instruction as well? If so, how often?

2. Are you mainly in charge of giving feedback in online instruction compared to in-person instruction or is it more learner-generated (peer corrective feedback)? Why?

3. Do you speak more (TT) in online instruction compared to in-person instruction? Why? How do you feel about it?

4. What is the atmosphere like in online instruction compared to in-person instruction? How does it affect student-instructor rapport?

5. Based on your personal experience, do students prefer online instruction to in-person instruction or is it vice versa? Why?

\section{Research methodology \\ Data collection}

All the data needed for this research were collected in interviews with four ELT instructors who are both level coordinators and senior teachers at the International University of Sarajevo's (IUS's) English Language School (ELS). We wanted to hear their first-hand experience with COVID-19 and emergency online instruction as well as their opinions through their answers to the research questions (listed in 2.7.). Four interviews were conducted in total during the month of December 2020. Each interview was conducted online (on MS Teams) and recorded for future reference.

\section{Participants and setting}

The four ELS level coordinators and instructors (one male and three female) who took part in this research are all experienced ESL teachers with at least fifteen years of experience in teaching. Out of those fifteen years of teaching experience, the majority of them have spent at least ten years teaching at ELS. Since English is the official language of communication at the International University of Sarajevo, English Language School is a prep school at IUS where students who decide to study at IUS have to take a Placement exam, which determines their level of proficiency in English. If they obtain sufficient number of points in the Placement exam, they take a Proficiency exam, and if they pass it, they can start their studies at the faculty of their choice at IUS. If they do not obtain enough points in the Placement exam, and depending on their results, they have to take courses of English at ELS, ranging from levels A1 to B2 (according to CEFR) (CEFR website and ELS Guidelines for students). ELS was accredited by Eaquals in 2017. Eaquals is one of the world leaders in accreditation for language teaching organizations (see Eaquals website). The authors of this paper have been working at ELS both as instructors and level coordinators for almost 14 years now, so they have the first-hand knowledge of the principles, rules and procedures as well as the experience with the ways both online and in-person instruction is conducted at ELS.

\section{Data analysis}

The interviews were conducted in English and the participants' answers to the research questions have been analyzed and some parallel points as well as differences have been pointed out in terms of both progressive/modern approaches and traditional approaches. The aim of this research is for it to be a case study "as an approach that involves an in-depth exploration of a single case, for example, of the phenomenon under study. A case may be based on any number of units of analysis: an individual, a group of individuals, a classroom, a school, or even an event." (Mertens 2010: 233, McDuffie and Scruggs as cited in Mertens 2010). That is why, our research questions are specific open-ended questions because we wanted to focus our research on some specific segments of the teaching/learning process at ELS in terms of its execution in online and in-person instruction, but we 
also wanted to give the participants enough space and freedom to share their experiences and views with us.

\section{Results and discussion Results analysis}

Table 1: Progressive/modern themes vs. traditional themes with regard to class activities

\begin{tabular}{|l|l|}
\hline Referenced Theme-Class activities & Number of References* \\
\hline Progressive/Modern approach & 1 \\
\hline $\begin{array}{l}\text { Pair work, group work and project work is done on a daily basis in } \\
\text { online instruction as well. }\end{array}$ & 4 \\
\hline $\begin{array}{l}\text { Online instruction procedures should be the same as in-person } \\
\text { instruction procedures. }\end{array}$ & $\begin{array}{l}\text { Teaching online is easier because all the digital media (video files, audio } \\
\text { files, etc.) are very easily accessible and the instructor likes the idea of } \\
\text { online chat rooms or group rooms. }\end{array}$ \\
\hline $\begin{array}{l}\text { The preparation of online classes takes much more time if the teaching } \\
\text { objectives and learning outcomes objectives are to be met. }\end{array}$ & 2 \\
\hline Traditional approach & 3 \\
\hline Pair work or group work is not conducted in online classes. & 2 \\
\hline $\begin{array}{l}\text { Private chat rooms or group rooms are not used regularly in online } \\
\text { instruction because the work does/will not get done. }\end{array}$ & 2 \\
\hline $\begin{array}{l}\text { It is difficult to organize pair work or group work online because } \\
\text { students are not ready for it. }\end{array}$ & 2 \\
\hline Online classes are mostly lecture-based. & 1 \\
\hline
\end{tabular}

*The number of references is the number of the interviewed instructors who mentioned or elaborated on the theme.

Table 2: Progressive/modern themes vs. traditional themes with regard to feedback

\begin{tabular}{|c|c|}
\hline Referenced Theme - Feedback & Number of References* \\
\hline \multicolumn{2}{|l|}{ Progressive/Modern approach } \\
\hline Feedback is mostly learner-generated. & 2 \\
\hline $\begin{array}{l}\text { Lower level students (A1-A2) are usually prompted or helped while } \\
\text { higher level students (B1-B2) should be more capable (of giving } \\
\text { feedback). }\end{array}$ & 2 \\
\hline Feedback is even more important in online lessons. & 2 \\
\hline \multicolumn{2}{|l|}{ Traditional approach } \\
\hline Feedback is mostly teacher-generated. & 2 \\
\hline $\begin{array}{l}\text { Individual feedback is given by the instructor through audio or video or } \\
\text { directly in online classes. }\end{array}$ & 2 \\
\hline $\begin{array}{l}\text { Peer feedback (peer editing), the way it is done in in-person instruction, } \\
\text { does not exist in online instruction. }\end{array}$ & 1 \\
\hline
\end{tabular}


Table 3: Progressive/modern themes vs. traditional themes with regard to TTT (Teacher Talking Time) \begin{tabular}{|l|}
\hline Referenced Theme - TTT (Teacher Talking Time) \\
\hline Progressive/Modern approach
\end{tabular}

\begin{tabular}{|l|l}
\hline The instructor generally speaks less in online classes. & 2 \\
\hline
\end{tabular}

When the instructor speaks, it is mostly to give instructions, set the task 2

or explain certain things.

Applying some physical activities in online classes/instruction or making 2

students work on some projects is important to shorten the amount of TTT.

\begin{tabular}{|l|l}
\hline The instructor gives short instructions, and, also, concrete examples are & 2
\end{tabular}

given to support the instructions.

\begin{tabular}{|l|l}
\hline The instructor speaks less in online instruction in order to keep the & 1
\end{tabular}

students' attention for a longer period of time.

\section{Traditional approach}

The instructor speaks much more in online classes. Number of References*

The instructor speaks more because he/she cannot see their students' 2

faces, so he/she tends to repeat his/her instructions or some answers and explanations, or even due to some technical difficulties.

The instructor speaks more and gets more tired in online classes, which does not happen in in-person classes.

The instructor speaks more because he/she does not have that sense of the students' presence and does not know how engaged they are.

*The number of references is the number of the interviewed instructors who mentioned or elaborated on the theme.

Table 4: Progressive/modern themes vs. traditional themes with regard to rapport Referenced Theme - Atmosphere/Rapport

Progressive/Modern approach

It depends on the dynamics of the group and on the students' level of 2 proficiency in English.

Working with smaller groups is more effective. Number of References*

There are not a lot of differences between online and in-person instruction in terms of the classroom atmosphere.

The instructor has to be much more hands-on in online classes.

Traditional approach

If the instructor does not know what the students are doing, the 3 atmosphere cannot be positive.

*The number of references is the number of the interviewed instructors who mentioned or elaborated on the theme.

Table 5: Student preference with regard to in-person and online instruction

\begin{tabular}{|l|l|}
\hline Referenced Theme - Student preference & Number of References* \\
\hline In-person instruction & 4 \\
\hline Students generally prefer in-person instruction. & 3 \\
\hline The socializing aspect is missing in online instruction. & 3 \\
\hline $\begin{array}{l}\text { Students are more involved in in-person instruction and some of them } \\
\text { think online classes are less important. }\end{array}$ & \\
\hline Online instruction & 2 \\
\hline $\begin{array}{l}\text { Students get to understand the advantages of online instruction } \\
\text { through time. }\end{array}$ & 2 \\
\hline
\end{tabular}

*The number of references is the number of the interviewed instructors who mentioned or elaborated on the theme. 


\section{Discussion \\ Class activities}

As it can be noticed from the results provided in Table 1, the interviewed instructors understand the importance of applying different class activities and classroom management methods. So, it is clear that the interviewed instructors are all aware of the benefits and potential of group work (Asher 1977, Ballard and Winke 2017, Palmer 1921, Krashen 1985, Krashner and Terell 1983, Long and Porter 1985, Winitz 1981). Furthermore, they acknowledge the fact that all necessary teaching materials are more accessible and can be used easily online. Some of them also understand the possibilities of online chat or group rooms which, in their opinion, could be exploited more in the future. However, the majority of them stated that they had not done it in their online classes yet. Moreover, what can be understood from their comments and elaborations is that it might be more challenging and difficult to organize pair work, group work or project work and that the preparation for those activities in the online setting takes more time.

Comment (1): There is no reason to change the in-person instruction procedures when teaching online.

Comment (2): It seems like a really good idea, but I haven't managed to apply that (pair work, group work, project work) in my online classes yet. But I'm going to. It's one of my goals.

Comment (3): I'm not a big fan of those private kind of chat rooms or group rooms because, at instances, I feel that things won't be done.

\section{Feedback}

As for the results shown in Table 2, one important thing to be emphasized here is the fact that one half of the instructors stated that feedback was learner-generated and the other half stated that it was teacher-generated, even though they all understand the importance of peer corrective feedback (Corder 1967, 1973, Panova and Lyster 2002, Selinker 1972). The elaborations given by the instructors who stated that feedback was learner-generated give us an insight into the importance of delegating feedback as well as the level of proficiency of students in question. Lower level students (A1-A2) seem to need to be more controlled and guided while doing it, while higher level students (B1-B2) seem to be more independent and better at doing it (what is also expected of them as far as the CEFR levels are concerned). At the same time, the instructors who stated that feedback was teacher-generated in their online classes reported that feedback was mainly given by them - on paper (digitally) and/or via audio or video. This might be some further evidence for the statement given by Sato (2013) that the environment might be crucial for the way feedback is given, and that the online environment might be both good or not good enough for its execution depending on the level of proficiency of students in question, the types of activities being done and/or the individual approach of the teacher/instructor.

Comment (4): I like delegating the feedback moment to students. It all depends on the levellower level students start with discussing certain questions and comparing their answers before discussing them together. As for higher levels - they should be more capable of doing it (giving feedback) but you still have to guide them. It's important for fostering their (learners') autonomy.

Comment (5): Now, it's basically me, only me doing all the feedback. As for in-person (individual) feedback, I do it via audio or video, not only on paper (digitally). I designate time to call the person or the persons up and actually have that one-on-one (feedback) through audio or at least through video where I would go step-by-step explaining the feedback to them in detail.

\section{Teacher Talking Time (TTT)}

Table 3 shows the results as far as the amount of TTT is concerned and whether and to what extent it changes depending on the mode of instruction (online or in-person). The instructors all acknowledge the importance of reduced TTT (Jarvis and Robinson 1997, McCormick and Donato 
2000), despite the fact that one half of them report to have spoken more in online classes, while the other half report to have spoken less in online classes, but they all seem to be aware of the fact that the teacher/instructor is the facilitator of the communicative activities and the environment in which it takes place, while the role of the learner is that of a communicator as argued by Antón (1999) in which she refers to Communicative Language Teaching (CLT) advocates. The instructors who stated that they spoke less in online classes said that they only spoke when giving instructions and when they needed to explain something in more detail. Another reason they mentioned (why) they spoke less was to make sure that they could keep their students focused on the lesson for as long as possible and that their increased TTT would definitely not make it possible. They also emphasized the importance of showing things and making sure their instructions were clear to their students. As for the instructors who spoke more in online classes, their main reason for doing it was that they could not see their students' faces at all or very rarely (due to their cameras and microphones being turned off) and consequently could not interpret their facial expressions and body language.

Comment (6): I speak less in online classes. The reason is really because I'm not quite sure that I can keep the students' attention for a longer period of time. That's easier to do in the (in-person) classroom setting.

Comment (7): I tend to keep the instructions short and I also don't expect longer answers from the students either, unless I ask them to prepare some kind of presentation or to answers some questions. If I give instructions, they are always followed by some kind of visual materials to make sure that they do understand. I'm a little bit more careful online, giving instructions online, basically.

Comment (8): I speak much more in online ... how do you call it? ... online instruction, online classes. I get more tired in online classes, which is not the case when I'm doing in-person teaching. Definitely, it's not the case.

\section{Rapport/Atmosphere}

It can be noticed from Table 4 that all the instructors believe that you have to be much more hands-on (prepared and ready for all sorts of circumstances that may occur) in online instruction in order to make the classroom atmosphere as positive and as effective as possible due to its importance for the learning/teaching process (Bygate, Skehan and Swain 2001, Ellis 2003, Sinclair and Coulthard 1975). Some of them stated that the atmosphere depended on the number of students in a group/class and their level of English, and that it was more convenient and effective to work with smaller groups of students. It was also argued that it depended on the very dynamics of the group. Some of them also argued that there were not a lot of differences between online and in-person instruction. But what the majority of them seem to agree on is that if you cannot see your students (because their cameras and microphones are generally turned off during online instruction) or you do not know what they are doing, the class atmosphere cannot be positive. Moreover, all the students at ELS and IUS are older than 18 , so, it is generally more challenging to influence them or "order" them to do something, compared to some younger students. This might go to prove the argument presented by Webb and Obrycki Barrett (2014) that the age of the student is a very important factor in building the positive atmosphere in class, both online and in-person.

Comment (9): It (atmosphere) depends on the level and it depends on the number of students in the group. Working with smaller groups, obviously, is very effective, in my opinion, and if they are higher level.

Comment (10): Applying some physical activity, even in online classes, is important for building the positive atmosphere.

Comment (11): The sense of presence is very important as well. In online classes, I don't have that sense of presence. The students are not there, I don't know what they are doing. Some are engaged but I feel that the majority is not that engaged, at least when it comes to teaching. 


\section{Student preference (online vs. in-person)}

As it can be clearly seen in Table 5, in-person instruction is definitely preferred by students by far. This was also observed and shown by Kelly and Columbus (2020). The instructors reported different reasons why their students preferred in-person to online instruction, varying from the socializing aspect or not having enough opportunities to interact with their peers to not being able to ask certain questions and get direct answers from their teachers/instructors as in in-person instruction. However, some of them also reported their students' eventual understanding and acceptance of the advantages of online instruction as well. This might change even further bearing in mind that distance learning is increasing in popularity and that the COVID-19 pandemic is not over yet. As for educational institutions around the world, for the time being, online instruction seems to be the only option if they intend to keep on running their businesses and earning any income in the present as well as in the foreseeable future.

Comment (12): I think number one is the social contact because they miss their friends, they miss sharing experiences and having a laugh, which you can't have online, or you can but to a certain extent. I think they would always go for the classroom setting, they would go for that. Comment (13): Most of them are viewing it (online instruction) as the only option that they would never choose if they didn't have to.

Comment (14): Students have to realize, and teachers have to realize as well, that online instruction has to be the same as in-person instruction. It has to be ... with all its limits and all it has ... it has to be.

\section{Conclusion and limitations}

What can be concluded is that, although the interviewed instructors all acknowledge the importance of applying modern teaching methods (such as pair work, group work, project works, learner-generated feedback and reduced TTT) in both online and in-person instruction, they seem not to be doing it in online instruction as much as in-person instruction. Their reasons for not applying them as much vary from their personal preferences, the technical difficulties they have experienced while working online, the level of motivation (or lack of) shown by their students, and many more. This all might make us believe that teachers/instructors are relying more on traditional approaches in their online instruction compared to in-person instruction, which could be supported by the fact that three out of the four interviewed instructors $(75 \%)$ reported that they had not done any pair work, group work or project work in their online classes, or that two of them (50\%) reported that they spoke more in online instruction compared to in-person instruction.

Another important point to be mentioned here is the inability of online programs to fully meet the needs of our modern and ever-changing world because

(...) in large part, online programs suffer from talking an easy-to-program, grammar-andvocabulary-driven approach to language pedagogy, sometimes even employing an online textbook. This one-size-fit-all, traditional approach cannot possibly yield results that learners seek and companies claim, such as the ability to speak fluently in a foreign language with coworkers in an international business (Doughty, 2015: 413).

Furthermore, Doughty (2015) argues that we do not have yet any large-scale empirical studies that would compare the outcomes of online and classroom language learning, since both online and classroom instruction offer practice outside the course in order for students to make progress, while brick-and-mortar classes are getting increasingly blended to provide students with the best of the both types of instruction.

However, we are aware that our results are based on limited data and that in order to prove this to a larger degree, more empirical studies, which would include a larger number of both students and teachers/instructors as well as the results of both types of instruction, would need to be conducted. Moreover, more time needs to be given to online instruction (the way it has been executed since the spring of 2020) and more results of this type of instruction need to be analyzed before we could make any solid conclusions in terms of its efficiency. Also, more feedback could be 
obtained from both students and instructors in terms of what can and needs to be done to improve online instruction even further.

\section{References}

Antón, M. (1999). The Discourse of a Learner-Centered Classroom: Sociocultural Perspectives on TeacherLearner Interaction in the Second-Language Classroom. The Modern Language Journal, 83(3), 303-318. Retrieved from: http://www.jstor.org/stable/330255.

Asher, J. (1977). Learning Another Language through Actions: The Complete Teacher's Guide Book. Los Gatos, CA: Sky Oaks Productions.

Bailey, J., Hess, F., Cerf, C., Conaway, C., El-Mekki, S., Erquiaga, D., Henderson K., Klaussmann D., Lewis W., Locket P., McQeen C., Rausch K., Rees N., Robinson G., Rotherham A., Rowe I., Scott I., Skandera H., Steiner D., Weiss J., \& White, J. (2020). (Rep.). American Enterprise Institute. doi: 10.2307/resrep24606.

Ballard, L., \& Winke, P. (2017). Students' Attitudes Towards English Teachers' Accents: The Interplay of Accent Familiarity, Comprehensibility, Intelligibility, Perceived Native Speaker Status, and Acceptability as a Teacher. In T. Isaacs \& P. Trofimovich (Eds.), Second Language Pronunciation Assessment: Interdisciplinary Perspectives. Bristol; Blue Ridge Summit: Multilingual Matters / Channel View Publications, 121-140. Retrieved from: http://www.jstor.org/stable/10.21832/j.ctt1xp3wcc.11.

Boumová, V. (2008). Traditional vs. Modern Teaching Methods: Advantages and Disadvantages of Each [online]. Brno, 2008 [cit. 2021-01-17]. Available at: https://is.muni.cz/th/f62v8/ Diplomová práce. Masarykova univerzita, Filozofická fakulta. Vedoucí práce Matthew Nicholls.

Breen, M., \& Candlin, C. N. (1980). The essentials of a communicative curriculum in language teaching.

Applied Linguistics, 1, 89-112.

Bygate, M., Skehan, P., \& Swain, M. (2001). Researching Pedagogic Tasks: Second Language Learning, Teaching and Testing. London: Longman.

Centers for Disease Control and Prevention (CDCP), Coronavirus Disease 2019 (COVID-19). 2020 Interim Case Definition, Approved August 5, 2020 https://wwwn.cdc.gov/nndss/conditions/coronavirus-disease-2019-covid-19/casedefinition/2020/08/05/.

Common European Framework of Reference for Languages (CEFR) https://www.coe.int/en/web/common-european-framework-reference-languages/leveldescriptions.

Corder, S. P. (1967). The significance of learners' errors, International Review of Applied Linguistics in Language Teaching 5, 161-170.

Corder, S. P. (1973). Introducing Applied Linguistics, Harmondsworth: Penguin.

Doughty, C. (2015). Accountability of Foreign Language Programs. The Modern Language Journal, 99(2), 412-415. Retrieved from http://www.jstor.org/stable/43650039.

Eaquals: Excellence in Language Education, www.eaquals.org.

Ellis, R. (2003). Task-based Language Learning and Teaching. Oxford: Oxford University Press

ELS Guidelines for Students, available in PDF.

In-person Learning - Definition. The Glossary of Education Reform for Journalists, Parents, and Community Members. Retrieved from https://www.edglossary.org/in-person-learning/.

Jarvis, J., \& Robinson, M. (1997). Analysing educational discourse: an exploratory study of teacher response and support to pupils' learning. Applied Linguistics 18, 212-228.

Kelly, A., \& Columbus, R. (2020). (Rep.). American Enterprise Institute. doi: 10.2307/resrep25358.

Krashen, S. D. (1985). The Input Hypothesis: Issues and Implications, New York: Longman.

Krashen, S. D., \& Terrell, T. D. (1983). The Natural Approach: Language Acquisition in the Classroom. Oxford: Pergamon.

Krashen, S. D. (1981). Second Language Acquisition and Second Language Learning. Oxford: Pergamon. Larsen-Freeman, D. (1986). Techniques and principles in language teaching. New York: Oxford University Press 
Long, M., \& Porter, P. (1985). Group Work, Interlanguage Talk, and Second Language Acquisition. TESOL Quarterly, 19(2), 207-228. doi:10.2307/3586827.

McCormick, D. E., \& Donato, R. (2000). Teacher questions as scaffolded assistance in an ESL classroom. In J. K. Hall and L. S. Verplaetse (Eds.) Second and Foreign Language Learning through Classroom Interaction, Mahwah, NJ: Lawrence Erlbaum Associates.

McDuffie, K. A., \& Scruggs, T. E. (2008). The contributions of qualitative research to discussions of evidencebased practice in special education. Intervention in School and Clinic, 44, 91-97.

Mertens, M. D. (2010). Research and Evaluation in Education and Psychology. Integrating Diversity With Quantative, Qualitative, and Mixed Methods. 3 Edition, SAGE Publication Inc.

Nunan, D. (1988). The learner-centred curriculum. Cambridge: Cambridge University Press.

Nunan, D. (1989). Designing tasks for the communicative classroom. Cambridge: Cambridge University Press

Palmer, H. (1921). The Oral Method of Teaching Languages. Cambridge: Heffer.

Panova, I., \& Lyster, R. (2002). Patterns of Corrective Feedback and Uptake in an Adult ESL Classroom. TESOL Quarterly, 36(4), 573-595. doi:10.2307/3588241.

Richards, J. (1990). The Language Teaching Matrix. Cambridge: Cambridge University Press.

Sato, M. (2013). Beliefs About Peer Interaction and Peer Corrective Feedback: Efficacy of Classroom Intervention. The Modern Language Journal,97(3), 611-633. Retrieved from http://www.jstor.org/stable/43651696.

Selinker, L. (1972). Interlanguage. International Review of Applied Linguistics in Language Teaching 10, 219-231.

Sinclair, J. M., \& Coulthard, R. M. (1975). Towards an Analysis of Discourse: The English Used by Teachers and Pupils. Oxford: Oxford University Press.

Top Hat, Adrift in a Pandemic: Survey of 3,089 Students Finds Uncertainty About Returning to College. news release, May 1, 2020, https://tophat.com/press-releases/adrift-in-a-pandemicsurvey/.

Volery, T., \& Lord, D. (2000). Critical success factors in online education. International Journal of Educational Management, 14(5), 216-223. doi.org/10.1108/09513540010344731.

Webb, N., \& Obrycki Barrett, L. (2014). Instructor-Student Rapport in Taiwan ESL Classrooms. Teaching \& Learning Inquiry: The ISSOTL Journal, 2(2), 9-23. doi:10.2979/teachlearninqu.2.2.9.

Winitz, H. (Ed.) (1981). The Comprehension Approach to Foreign Language Instruction. Rowley, MA: Newbury House. 